January 1983

\title{
Olfaction and Sexuality
}

Michael Buxbaum, MD

Thomas Jefferson University

Follow this and additional works at: https://jdc.jefferson.edu/jeffjpsychiatry

Part of the Psychiatry Commons

Let us know how access to this document benefits you

\section{Recommended Citation}

Buxbaum, MD, Michael (1983) "Olfaction and Sexuality," Jefferson Journal of Psychiatry. Vol. 1 : Iss. 1 , Article 3.

DOI: https://doi.org/10.29046/JJP.001.1.002

Available at: https://jdc.jefferson.edu/jeffjpsychiatry/vol1/iss $1 / 3$

This Article is brought to you for free and open access by the Jefferson Digital Commons. The Jefferson Digital Commons is a service of Thomas Jefferson University's Center for Teaching and Learning (CTL). The Commons is a showcase for Jefferson books and journals, peer-reviewed scholarly publications, unique historical collections from the University archives, and teaching tools. The Jefferson Digital Commons allows researchers and interested readers anywhere in the world to learn about and keep up to date with Jefferson scholarship. This article has been accepted for inclusion in Jefferson Journal of Psychiatry by an authorized administrator of the Jefferson Digital Commons. For more information, please contact: JeffersonDigitalCommons@jefferson.edu. 
Michael Buxbaum, M.D.

A patient who describes himself as "sanitary" told me of his concern with odors. Whenever he thinks about establishing a sexual relationship, he develops a fear that his partner may smell offensive, especially around her genital area. He describes signs and symptoms of sympathetic overactivity when he engages in foreplay, and is afraid that he might be impotent if he smells anything offensive. In fact, he has to insert a finger into his partner's vagina during foreplay, to test the nature of the odor. He feels relieved when the smell is neutral or perfumed, and demonstrates enhanced sexual performance. The patient, who uses deodorants extensively, reports pleasurable sensations when he sits in the bath and smells his own flatus bubbling through the water. Between the ages of five and seven, he recalls smelling his mother's flatus; he is anxious and embarrassed when he describes this incident in therapy. This anxiety is qualitatively similar to the anxiety he experiences during foreplay.

This brief vignette highlights the importance of odors in the sphere of human sexuality. It also suggests that odors now considered repulsive were stimulating in an earlier developmental period. Since olfaction plays a role in human development, many psychiatric patients report interesting olfactory symptoms. This article focuses on the relationship between olfaction and human sexuality.

Hippocrates was aware of a relationship between sexual development and olfaction; he noted that the sexual odors are not of adult quality until puberty. Smell is represented as a powerful sexual stimulus in various literary works, including those of Shelly, Baudelaire, Zola, and Shakespeare(1). Freud was impressed by the result of the lifting of the human nose from the earth when man assumed an upright posture. He believed the consequence was that a number of pleasurable sensations connected with the earth became repulsive, and that the loss of the sense of smell might be a part of repression of sexual drive, consistent with advancing civilization(2). In the "Three Contributions to the Theory of Sex," Freud stated in regard to fetishism:

Selection of the fetish depends on the coprophilic smell desire which has been lost by repression. Feet and hair are strong smelling objects which are raised to fetishes after renouncing the now unpleasant sense of smell. Accordingly only the filthy and ill smelling foot is the sexual object in the perversion corresponding to foot fetishism(3).

Dr. Buxbaum is a third year psychiatry resident. 
The sense of smell is strongly connnected to sexuality, and therefore is subject to repression and other forms of modification by the ego. The anatomical nose itself is one of the symbols for the penis. The story of Cyrano de Bergerac stands out among other examples in fiction. The popularity of rhinoplasty may be partially explained by the wish to conceal an organ which responds to unacceptable odors. Material from analysis of dreams frequently shows a relationship between nose bleeds and castration anxiety in men and menstruation (representing loss of the penis) in women.

There seem to be developmental changes in the conscious perception of odor. Infants and younger children find the natural smell of body secretions pleasant and exciting. Later in life, these odors are perceived as repulsive and unstimulating. There is evidence that preoedipal children can discriminate their own smell from that of others. Infants also discriminate their own mothers' breast pads as early as the first two days of life(4). Stein (5) exposed 300 normal children to the smell of sweat and synthetic feces, and found that children younger than four reacted positively, while chldren older than six exhibited a negative reaction. The switch in the quality of perception of odors seems to occur between the ages of four and six, during the oedipal phase of development.

We could speculate that it must be exciting for a child to smell his mother's natural scents and to be stimulated by them. As development progresses, the child's ego cannot allow this incestuous excitement, and consequently this sense of smell is repressed along with other libidinal impulses present in this developmental period. Kalogerakis (6) describes a case of a boy between the ages of two and five years, who was stimulated by olfactory perceptions but gradually repressed them.

Some research has been directed towards identification of specific substances, pheromones, which are thought to modify behavior through olfaction. These compounds have not yet been demonstrated in humans, but do play an important part in the life of lower animals, especially insects. In humans, they are thought to be similar to sex hormones in structure and to have a musk odor. Interestingly, the olfactory system is the only sensory system with a direct connection to the limbic system, where the centers associated with sexual arousal are located. In theory, the best evidence for the action of pheromones is the phenomenon of menstrual synchrony. Two recent studies $(7,8)$ demonstrated menstrual synchrony between close friends, who lived in proximity for a period of four months. This synchrony does not occur between neighbors who are not friends. Another study (9) showed that, after a woman's sweat was applied to the upper lip of female volunteers synchronized their cycles within four months.

Several studies have been done to demonstrate the possible effect of steroid sex hormones on human behavior. All have serious methodical problems, and the evidence to be drawn from them is conflicting(4). A recent study (10) shows no effect of androstenol on perceived physical attractiveness between men and women. It is also interesting that the tissue covering the middle and inferior turbinates and a portion of the 
nasal septus is anatomically similar to the erectile tissue of the penis. Several studies show correlation between sexual excitement, menstruation, and pregnancy and changes in the nasal mucosa, notably hyperemia, hypersecretion, and nasal stuffiness. The act of coitus produces a rise in temperature of the nasal mucosa, as well as a state of vasodilation and an associated increase in the blood supply of the nasal mucosa(11).

The connection between olfaction and sexual stimulation in adult life should not be underestimated. This stimulation is often produced by artificial, institutionalized odors. These are scents characteristic of the variety of cosmetic products available on the market. Their importance is indicated by their seemingly endless numbers, their widespread usage and commercial success. Perhaps this usage demonstrates the human search for highly personal, yet socially acceptable smells. Here we may be seeing a revised, modified representation of an older, regressive interest in body odors. The repressed childhood interest had to be replaced by wide spread use of artificial scents during both sexual and nonsexual activities.

of course, a small minority of the population continues to favor the odor of natural body secretions, such as sweat, urine, and feces. In certain perversions, a pungent smell is required for sexual arousal and orgasm. Before psychotropic medications were available, regressed schizophrenic patients were frequently observed to be preoccupied with their own excretions, hoarding feces, smearing them on their bodies and even eating them. We can thus hypothesize that the developing ego represses the excitement associated with odors of natural body secretions, along with other libidinal impulses of the preoedipal period, and institutes a defensive modification of what is considered a pleasurable smell. In certain pathological states, the ego regresses and we can observe pleasurable sensations associated with odors usually considered repulsive.

In conclusion, strong connections exist between olfaction and human sexual behavior. In psychiatric practice, we often hear interesting olfactory data from our patients and are told how the sense of smell affects their existence. Childhood research material indicates that the perception of smell passes through certain developmental stages and, like other aspects of sexuality, is subject to repression and other modifications by the developing ego. When the outcome of such modification is normal, the odors once considered exciting will become offensive. odors of different quality become stimulating in normal adulthood, yet personal preferences probably continue to depend on childhood memories of odors. In pathological cases the modification of olfaction by the ego is arrested or incomplete, and one sees various inappropriate behavior. Anatomic and physiologic similarities and connections between the olfactory and sexual apparatus have been demonstrated. This connection has also been extensively utilized in literature and art. The role of pheromones in human sexual behavior is not established. 
1. Ellis H: Studies in the Psychology of Sex, Volume 1, Part 3. New York, Random House, 1936.

2. Freud S: Civilisation and Its Discontents. London, Hogarth Press, 1951.

3. Freud S: Contributions to the Theory of Sex. In The Basic Writings of Sigmund Freud, New York, Random House, p 569, 1938.

4. Rogel MJ: A critical evaluation of the possibility of higher primate reproductive and secual pheromones. Psychological Bulletin 85:810-830, 1978.

5. Stein M, ottenberg F, Roulet $\mathrm{H}$ : Study of the development of olfactory preferences. AMA Archives of Neurology and Psychiatry 30:264, 1958.

6. Kalogerakis MG: The role of olfaction in sexual development. Psychosomatic Medicine 25:420-432, 1963.

7. McClintock MK: Menstrual synchrony and suppression. Nature 229:244-245, 1971.

8. Graham CA, McGrew WC: Menstrual synchrony in female undergraduates living on coeducational campus. Psychoneuroendocrinology 5:245-252, 1980.

9. Russell MJ, Switz GM, Thompson K: Olfactory influences on the human menstrual cycle. Paper presented at the meeting of the American Association for the Advancement of Science, San Francisco, June 1977.

10. Black SL, Biron C: Androstenol as a human pheromone. Behavioral and Neural Biology $34: 326-330,1982$.

11. Fabricant ND, Neffson AH: Sexual functions and the nose. American Journal of Medical Science 4:156-160, 1960. 